\title{
Negotiating "Istrian-ness" in tourist \\ historiography: Observations on the discursive formation of a regional identity
}

\author{
Eva Posch
}

\author{
Preliminary communication \\ UDK 338.482:930(497.571) \\ 316.4:316.334.5(497.571) \\ 39:338.482(497.571)
}

\begin{abstract}
Identity and identities at the national and regional levels may be perceived as being in a constant state of flux. They are, however, primarily and continuously subject to negotiation. The narratives of history in tourist media provide space for this negotiation and facilitate mediation of discourses on identity conceptualisation. The present paper will thus investigate how the conceptualisations of regional identity in Istria are mediated through tourist historiography. In the introductory part, relations between identity formation and tourism will be discussed. The empirical part will then investigate tourist historiography from Istria and discourses on regional identity with specific emphasis on representational and narrative strategies used to mediate these discourses to a tourist audience.
\end{abstract}

Keywords: tourism, historiography, identity discourses, region, Istria

\section{Introduction}

The close link between tourism and identity formation has been proven. With regard to identity configuration in the context of nation-building in particular, a range of studies on the significance of tourism have been published in recent decades, demonstrating the claim that this phenomenon has been closely studied (Sears 1989, Shaffer 2001, Zuelow 2009, Graml 2004). Both share 
the aspect of ordering human and non-human environments, and the sites/sights, monuments and other points of interest serving as national attractions, which are first constructed by nationalist discourse and then more broadly employed, represent this close link. Franklin observed that it was the ordering process of $19^{\text {th }}$-century nation formation that provided sights and attractions to the members of a nation and thus instigated mass tourism by incorporating social groups who had up to then been sedentary and locally and regionally bound into a national culture of travel (Franklin 2004: 279). Thus, tourism and nation formation share not only a similar internal structure but also a history. Regarding national identity, visits to nationalized sights and attractions promote affirmation of identity conceptualisations as well as the appropriation of one's own nationhood through tourist practices (Palmer 1999: 315-318; 2005: 13). This can be specifically observed in cases of visiting heritage sites or places of historical interest and affirmation of the historical dimension of national identity (Klekot 2010: 274-276). All of these tourist sites, sights and attractions do not possess an inherent meaning, rather they are socially constructed spaces (Wöhler et al 2010: 11); and they require the provision of representational systems to mediate their narrations and meaning to a tourist audience (Rojek 1997: 53-54). These representational systems comprise all forms of tourist media: informative and promotional material such as leaflets, brochures, guides, magazines and interpretative signage in situ as well as promotional websites.

Besides their most obvious purpose of catering to tourists and providing them with more or less sought-after information, these media have additional significance in that they provide a space for the mediation of a variety of nationalized discourses and the discursive negotiation of national identity. For example, narratives of history in tourist media, i.e. "tourist historiography", mediate discourses on the historical dimension of national identity. A visit to these sites and the consumption of the available representational media promote the affirmation of identity conceptualisation with a co-national audience, who have often been exposed to mediated discourses via the politics of history and identity in educational or public spheres. A non-national audience will have a different form of reception. Foreign and international tourists have not been exposed to national identity politics and usually depend a great deal on the consumption of tourist media for interpretation. They, however, are considered vital "identity builders" as they constitute an external audience to whom notions of nationhood are projected and who act as disseminators of these concepts (Pitchford 2008: 3). 
Within the framework of the present study, these considerations on the close relationship between tourism and nation-building are relevant because nations and regions share some noteworthy characteristics. Very much like nations, regions are social constructs, based on social practices, processes and discourses; and much like nation-building, region-building is promoted by regional elites with their own interests and their own stake in strong, independent regions; much like nation-building, region-building leads to the creation of a set of discourses and strong regional symbolisms in terms of naming, imaging and, not least, branding. Much like nation-building, region-building frequently makes use of cultural practices and traditions, historical narratives, a traditionally occupied territory, linguistic commonality and the existence of shared awareness of the common provenance of the regional population. Paasi stated that once regions are successfully established by acquiring administrative autonomy, they are then reproduced through social practices and discourses in regional politics and in the economy, media, culture and education (Paasi 2009: 133). Though not included in these observations, this enumeration should be extended to one more vital field of identity discourse mediation, tourism: Much like the nation, one may assume that a region can be reproduced through discourses mediated through tourism and tourist practices.

If, in a national context, tourist media and, specifically, the narratives of history therein have been shown to provide space for the discursive negotiation of national identity, this circumstance warrants the question as to whether a similar mechanism can be observed at a regional level, or to pose the question differently and more clearly: Are narratives of history in regional tourist media also spaces where the historical dimension of regional identity is discursively constructed and negotiated?

This novel angle of research shall be investigated in tourist media from the Eastern Adriatic destination Istria. The peninsula has historically been a popular tourist destination, notably since the $19^{\text {th }}$ century, when - promoted by members of the Austro-Hungarian aristocracy - seaside resorts along the Istrian and Dalmatian coasts commenced to pull tourists from upper-class and bourgeois backgrounds to the so-called "Austrian Riviera" (Baskar 2010: 10-17). Yugoslav socialist tourism policies encouraged further commercialisation of the Istrian resorts, this time by providing holidays to the new social class of workers backed by an ideology of work and leisure, and by way of promoting coastal tourism to international guests (Grandits and Taylor 2010: 3-6). Centralized tourism policies in Socialist Yugoslavia very much aimed at attracting foreign tourists to gain 
international political legitimization, especially after the break with Moscow demanded a re-orientation towards Western Europe (Tchoukarine 2010: 111118). Tourism proved to be one of the major sources of income and foreign investment for the socialist Yugoslav state, but tourism promotion had a singular focus on coastal resorts and the heritage of urban centres, while excluding hinterlands and rural areas alike. After the break-up of the Yugoslav federation and the Balkan wars of the 1990s, successor states faced both the need for nation-building and for re-branding their new nation states as tourist destinations (Hall 2002: 20-25; 2004: 117-122) In Croatia, for example, this resulted in a dissociation from recent history and the promotion of a nationalized account of the past within tourist contexts, as well as emphasis on historical ties to Western European culture to stress its European character and to distance itself from any possible associations with the "East" (Rivera 2008: 620-624). However, these nationalized representations of history did not go down well with all segments of tourists, especially those visiting Adriatic coastal resorts because they expected projections of a cosmopolitan maritime heritage rather than nationalized re-interpretations of history (Cocco 2010: 39). This general trend of nationalization must be understood within the broader ideological and political framework after the so-called democratic revolutions of 1989-1991 in Central, South-eastern and Eastern Europe, when national self-determination was believed to have finally overcome centuries of foreign, imperial rule. Thus, newly established statehood was determined by ethnically-denoted nation formation, leaving little room for aspirations to a regional or local level. This neglect echoed previous centralizing socialist policies. with their general disregard for local or regional identities (Batt 2002: [1]-4.)

Istria, especially that part of the peninsula situated within the borders of present-day Croatia, had a strong sense of regional independence which had developed during the decades of Yugoslav leadership and which was due to successful economic development and the growth of regional tourism. After the collapse of Yugoslavia, the Istrian population supported Croatian nation-building, but expected to retain their regional autonomy. The centralizing policies pursued by a nationally inclined Croatian government under Franjo Tudman's Croatian Democratic Union (HDZ), however, threatened to underscore regional independence and thereby reinforced attempts at regional politics and the respective political movement exemplified by the Istrian Democratic Assembly (IDS), a party that represented regionalism and purported to work for economic 
and political stability in Istria within a wider European rather than a narrower Croatian national framework (Ashbrook 2011: 874-879).

These close relations between regional policies and the aspirations of local political forces were not limited to Istria but can be witnessed in many different European regions, where promoting regionalism has frequently served as a tool to pursue a different political agenda than that prescribed by the national centre and thus maintain a certain regional independence without actually pursuing secession (Ford 2007: 287). Tourism has proven to be a valuable tool for regionalist agendas, creating a sense of regionalism by developing and promoting a geographically, historically or culturally defined region as a tourist destination (Murdoch 2007: 606). Moreover, regionalism has acquired a significant role within the context of the European Union thanks to the political agenda of the "Europe of regions". The latter thereby initiated a regional push in many parts of Europe: this agenda has effectively fostered the creation of new meaning for the region as well as the "rescaling of state space" and a re-interpretation of the meaning of territoriality (Paasi 2009: 123).

The above considerations justify an investigation into the discursive negotiation of a regional Istrian identity in a tourism context by analysing the narrative and representational strategies used to conceptualise and mediate this identity in tourist historiography from Istria. On a meta-textual level, the analysis will contextualize these discourses within the framework of the current political and societal issues and debates that characterize Istrian regionalism. The research will be based on a sample of current foreign tourist media, published in print or online in Istria and available at resorts and at sites throughout the peninsula, or online from clearly commercially oriented promotional websites of Istrian origin.

\section{Representational and Narrative Strategies in Tourist Historiography from Istria}

Narratives of an ancient civilisation on the peninsula are employed to indicate the origins and a provenance of the present-day Istrian population, for example: "The earliest known settlers were the Histri, a prehistoric tribe. Life in 
hillforts and their customs, as well as their glorious wars against the Romans, left an indelible imprint on this region". ${ }^{1}$

They indicate the continuous existence of an indigenous population which is projected into the antique past. They are not identified as an ethno-national community or a prototype thereof, instead, the Histrians represent the civilizational and cultural components of a regional identity. Thus, they possess symbolic significance as an early indigenous population on Istrian territory. In contrast to nationalized narratives of origins in tourist historiography, there is no direct identification between the present-day Istrian population and their historical predecessors. The accounts on early Histrians rather serve to establish early indigenous ancestor populations that have marked the peninsula by giving it their name and they have come to be seen as civilizational predecessors. Moreover, narratives about the Histrians also promote the mental mapping of Istria, thereby historically and geographically anchoring the region:

Istria was named after the Illyrian tribe of the Histri. It is said that they came on these areas because of water, settling the regions from the Timava River to Mount Učka and the Raša River respectively. The custom of incineration appeared in the $11^{\text {th }}$ century $B C$ and represents one of the typical characteristics of the culture of the pre-historic tribe of the Histri." 2 The Histrians were the first known inhabitants of the Istrian peninsula, and they are mentioned in historical writings of the Ancient Greeks and Romans. The peninsula carries the name of these ancient people of IndoEuropean origin who emerged at the beginning of the Iron Age. In addition to hunting and fishing, and raising goats and sheep, they also engaged in pirating, and historians refer to them as a dangerous people. The Histrians traded with the Greeks, believed in multiple deities and worshipped goddesses. $^{3}$

The Histrians are also represented as a first indigenous civilization to succumb to Roman occupation and civilization, not without putting up some heroic resistance, personalized by a mythological leader-figure:

\footnotetext{
${ }^{1}$ Gordana Restović et al, Istria: Il sigello della storia Istra/The Imprint of Time, Pula 2011, 8.

${ }^{2}$ http://histrica.com/g/history/ (last accessed 29 April 2015).

${ }^{3}$ http://www.coloursofistria.com/en/destinations/istria/history (last accessed 26 November 2015).
} 
The Histrians lived undisturbed lives, until they came into conflict with the Romans because of their pirating in the northern Adriatic. The historian Titus Livius wrote in detail of the defeat of the Histrians at the hands of the Romans in wars during the late 3rd and early 2nd century BCE. King Epulon led the Histrian tribes into battle. The final confrontation took place at the Histrian stronghold Nesactium near Pula. The Romans laid siege, and Epulon and his soldiers, realising they had no way out, committed suicide. Despite being defeated, the Histrians continued to live for some time in their hill-forts throughout Istria. [...] In the mid-1st century BCE, during the rule of Gaius Julius Cesar, the Romans pushed the Histrians into the interior of Istrian away from the coast, where they settled their own people and established the colonies of Pula and Poreč. ${ }^{4}$

Narrative representations of Histrians thus serve the purpose of providing the present-day Istrian population with projections of continuity back into the past, of establishing a historical territory and a cultural and civilizational predecessor population. In that regard, discourses on the historical dimension of Istrian regional identity are very similar to those employed in nationalized tourist historiography from other destinations across South-eastern Europe (Posch 2015: 166-173). However, within an Istrian context, tourist historiography does not establish the Histrians as the ethno-national core of the modern Istrian population, i.e. their direct ancestors. This approach of not framing Istrian regional identity as an individual ethno-national identity can be easily explained if current Istrian identity politics are taken into account. These promote a contrastive conceptualisation of Istrian-ness as a composite "hybrid" identity, as Ballinger (2004) observed:

In contrast, many inhabitants of contemporary Istria [...] advocate a view of Istrian identity as multi-ethnic, multicultural, and multilingual. Though I have heard the term "hybridity" (ibridisimo) used, Istrians usually draw on other terms expressing fusion: "mixture" (mescolanza), "mosaics" (mosaico), bilingualism or di/triglossia, and "cohabitation" (convivenza) (Ballinger 2004: 32, italics in the original).

\footnotetext{
${ }^{4}$ http://www.coloursofistria.com/en/destinations/istria/history (last accessed 26 November 2015, bold letters in original).
} 
The nationalizing policies of the central government in Zagreb and the intended curbing of Istria's traditional independence have led to the politicization of the regional Istrian identity, thus endowing it with political weight while also making it a valuable tool for the regional movement and its political representatives (Ashbrook 2011: 887-888).

Narratives reflecting the "hybrid" core of Istrian regional identity prevail in tourist historiography from Istria, specifically emphasizing a rich and diverse history of various civilizations on the territory of the Istrian peninsula. "Istrianness" is conceptualized as a plural, multi-cultural regional identity, sourced from the encounters of different civilisations, their cultures and traditions, on the territory of the Istrian peninsula throughout history:

Der römische Sieg über die Histrier öffnete den Zugang für hundertjährige Veränderungen und Abfolgen von Herrschern, Grenzen und Kulturen, der Bevölkerung, sowohl auf dem Festland als auch auf dem Meer und an den Flüssen. - Istrien war in der Geschichte das Gebiet des Zusammentreffens vieler Völker und der Durchdringung ihrer Kulturen, Liburner, Histrier, Griechen, Kelten, Römer, Ostgoten, Byzantiner, Langobarden, Kroaten, Franken, Venezier, Österreicher, Italiener und Slowenen prägten Istrien mit ihrem Leben, ihren Bräuchen, ihrer Arbeit und waren tief in alle Teile Istriens verwoben. ${ }^{5}$

This plurality is expressed both in tourist media at the regional level (as evident in the above quote) and at the local level, and across the region, such as in a brochure about the Croatian town and popular seaside resort Pula, where an image of its Roman amphitheatre symbolises the cultural diversity in the city's long history, under the title Pula, rendez-vous in the Adriatic:

It seems as though the amphitheatre of Pula does not have enough "windows" to frame with its stone arches all the images of the voyage in time. This is the sixth largest Roman amphitheatre in the world; certainly

5 Gordana Restović et al, Istrien/Istrie: ein Abbild der Zeiten/l'empreinte du temps, Pula 2011., 6: "The Roman victory over the Histrians opened the way for centuries of change and a succession of rulers, borders, and cultures of populations, both on terra firma as well as on the sea and along the rivers. - Istria was historically a region of contacts between many different peoples and the interaction of their cultures: Liburnians, Histrians, Greeks, Celts, Romans, Ostrogoths, Byzantines, Lombards, Croats, Franks, Venetians, Austrians, Italians and Slovenes marked Istria with their lives, their customs and their work, and they were deeply woven into all parts of Istria." 
the most beautiful by its elegance. Between the mythical tradition and the three thousand years of continuity it is a unique place that gathers so many civilization differences. The memories of Pula are made of traces of its distant inhabitants, the Histri, from Classical, Romanesque-Gothic structures and Baroque, from the Austrian Secession architecture, the Italian Novecento and contemporary creations. ${ }^{6}$

A similar representation can be seen in the following quote, again with a focus on the local, from the Slovenian town of Koper:

The indelible traces of permeation of ancient Mediterranean and continental cultures can be seen all over the town. We are always in the same town even though we speak about one-time Greek Egida, the first Roman island settlement Capris (the Isle of Goats), the Byzantine Justinopolis, the Venetian capital of Istria Capo d'Istria (literary, the Head of Istria), Croatian Kopar and Slovene Koper."

What all these narratives share is the tendency to represent Istria as a meeting-place of many different populations and their cultures, merging throughout history to arrive at an amalgam which is the basis for the present-day understanding of "Istrian-ness". However, the representations marked by this depiction of "Istrian-ness" are only superficially inclusive as they only allow narratives that support the notion of "Istrian-ness" but do not provide an alternative account or additional historical aspects. For this purpose, historical accounts employ narrative strategies of appropriation and reframing of history. A prominent example is the re-framing of the history of Venetian Istria, and the appropriation of its historical, cultural and architectural heritage.

Historically, Istria was of crucial importance to the emerging maritime power Venice, and it became part of the former's sphere of influence during the early phases of Venetian expansion into the Eastern Adriatic, before it went on to finally become an integral part of the Republic of Venice (Lebe 1987: 22-70). These historical periods have left traces throughout Istria in its architectural and

\footnotetext{
${ }^{6}$ Tourism Office Pula (ed), Pula is more - Pula je vice, without pagination or year of publication. This brochure is part of a series of tourist brochures with the title Pula + , which are available online and at sites across the city.

7 Venetian Architectural Heritage in Istria, published in the project "Heart of Istria, Culture and Heritage of Istria, Development of Cross Border Tourist Itineraries in Urban and Rural Areas of Istria", supported by the Neighbourhood Programme Slovenia-HungaryCroatia of the European Union 2004-2006, p. 22.
} 
cultural heritage, marking Istrian town- and cityscapes. As a tourist destination, Istria can thus offer sites and attractions visibly influenced by Istria's Venetian history.

All across the peninsula, the Venetian architectural heritage bears witness to this, and it features centrally in the development and promotion of Istria as a tourist destination, as evidenced by the publication of a brochure entitled Venetian Architectural Heritage in Istria. The analysis of this tourist media shows that Istrian tourist historiography engages a narrative strategy of appropriation by regionalizing and localizing Venetian-Istrian history. The narratives provided in the brochure employ strategies of regionalisation by stressing Istrian agency in the creation of the environment constructed in the Venetian style: Istrian limestone quarries are presented as a major source for the Venetian construction industry; Istrian craftsmen are depicted as exporting their skills as far afield as Venice; even the Venetian origins of local architecture are disputed, as a "regional house style" is emphasized, which is portrayed as a "rural Istrian development", only later to be modified by Venetian influence. ${ }^{8}$

These narrative strategies of localization and regionalization work most successfully in representations of the history of specific towns and places and their architectural heritage as well as personal legacies. The brochure on Buje, for example, provides the following information:

The very compact historical town nucleus is full of buildings with wellknown stylistic elements from the $15^{\text {th }}$ to the $19^{\text {th }}$ centuries. The most picturesque is a small, one-storey house, situated on the west side of the central old-town square [...] The remains of the painted decoration, showing red and white squares in succession, could be seen on the façade. Painted external decoration is not a typical feature in Istria, except for Koper, but such decorations are common in the Veneto region. The Doge's Palace in Venice is the most famous example of the decorated façade. ${ }^{9}$

Therefore, the Venetian heritage is strongly represented in tourist historiography, but within a localized or regionalized framework of interpretation. This results in the de-contextualisation of actual history and a falsified or superficial historical account through the omission or reinterpretation of historical facts, a common phenomenon in tourist

\footnotetext{
${ }^{8}$ Venetian Architectural Heritage in Istria, 5. See also footnote 7.

${ }^{9}$ Venetian Architectural Heritage in Istria, 11.
} 
historiography (Posch, 2012: 304-312). This narrative strategy is also underscored by the representations of the Winged Lion of Saint Mark in tourist media, a pervasive feature of Istrian townscapes and an outstanding example of the Venetian claim to power in the Eastern Mediterranean. Its presence is acknowledged, for example, as a "Symbol der Anerkennung der venezianischen Herrschaft in Labin"10. This quote indicates that the Venetian political and administrative presence across Istria is seen as foreign rule which had to be recognized when, in fact, Istria was historically an integral part of the Republic of Venice. Besides, the true significance of the Winged Lion of Saint Mark as a powerful symbol of medieval and early modern Venetian statehood and political and military hegemony throughout the Eastern Mediterranean is also omitted when, in reality, the extent and significance of the Venetian maritime empire and the multicultural Venetian Commonwealth stretching all the way down to the Levantine shore entailed multiple economic and cultural encounters for all those regions in between (Rothman 2012: [10]-[11]). Representations taking into account the extent to which the historical development of the peninsula was a consequence of the economic, political and military power of the Venetian republic are, however, sacrificed in order to mediate a sense of a continuous independent development of the Istrian region.

\section{Conclusion}

Historical narratives in tourist media, i.e. tourist historiography, provide a space for the negotiation of identity conceptualisations through the mediation of discourses. This has become evident within the context of nation formation. The present study on tourist historiography from the Istrian peninsula, a popular tourist destination on the Eastern Adriatic coast, shows that these observations are also valid with regard to the formation of regional identities. In this specific example, the highly-politicized conceptualization as a multi-cultural, multi-lingual and multi-ethnic composite Istrian identity is negotiated through narratives of the ancient Histri civilization, aimed at providing the "Istrian-ness" with an indigenous provenance on Istrian territory with an ancient civilizational and cultural heritage, thus emphasizing the existential continuity of the Istrian population on the peninsula, but forgoing any ethno-national distinction and thereby contrasting more common representations in nationalized tourist

10 Istria Tourist Board (ed.) Enjoyistria no. 26, Spring-Frühling, Poreč 2013, 28: as a "symbolic acknowledgement of Venetian rule in Labin". 
historiography. Another narrative strategy can be seen in the appropriation of the Venetian cultural and architectural heritage by regionalizing and localizing narratives. These result in historical de-contextualisation and a reframing of actual history as Istrian history, endowing the region with a sense of individual historical development and historical independence, which is, in fact, a reinterpretation of the actual history.

The employment of these representational strategies have to be viewed with regard to the overall tourism branding strategies to present Istria as a region in itself and thus to promote Istrian historical and cultural heritage as independent from Croatian or Slovenian tourism promotion. But moreover, these narratives mediate discourses of region-building based on an understanding of Istria as a historically developed region and a conceptualization of regional identity as different from surrounding national identities, as a composite multi-cultural, multi-lingual and multi-ethnic identity.

\section{Bibliography}

\section{ASHBROOK 2011}

John Ashbrook, "Politicization of identity in a European borderland:

Istria, Croatia, and authenticity, 1990-2003," Nationalities Papers, 39/6, Oxford 2011, 871-897.

\section{BALLINGER 2004}

Pamela Ballinger, "'Authentic Hybrids' in the Balkan Borderlands," Current Anthropology, 45/1, Chicago 2004, 31-60.

\section{BASKAR 2010}

Bojan Baskar, "Southbound, to the Austrian Riviera: The Habsburg Patronage of Tourism in the Eastern Adriatic," Anthropological

Notebooks, 16/1, Ljubljana 2010, 1-22.

BATT 2002

Judy Batt, "Introduction: Regions, State and Identity in Central and Eastern Europe," Regional \& Federal Studies, 12/2, Oxford 2002, 1-14.

\section{COCCO 2010}

Emilio Cocco, "Performing Maritime Imperial Legacies: Tourism and Cosmopolitanism in Odessa and Trieste," Anthropological Notebooks, 16/1, Ljubljana 2010, 37-57. 
FORD 2007

Graham Ford, "Constructing Regional Identity: The Christian Social Union and Bavaria's Common Heritage 1949-1962," Contemporary European History, 16/3, Cambridge 2007, 277-297.

FRANKLIN 2004

Adrian Franklin, "Tourism as an ordering. Towards a new ontology of tourism," Tourist Studies, 4/3, London et al 2004, 277-301.

GRAML 2004

Gundolf Graml, Remapping the Nation: Tourism, Space, and National Identity in Austria after 1945, unpublished Ph.D. thesis, Minnesota 2004.

GRANDITS ET AL. 2010

Hannes Grandits, Karin Taylor, "Tourism and the Making of Socialist Yugoslavia: An Introduction," in: Yugoslavia's Sunny Side: A History of Tourism in Socialism (1950s-1980s) (eds. H. Grandits and K. Taylor), Budapest et al 2010, 1-32.

HALL 2002

Derek Hall, "Brand development, tourism and national identity: The reimaging of former Yugoslavia," Brand Management, 9/4-5, London 2002, 323-344.

HALL 2004

Derek Hall, "Branding and national identity: The case of Central and Eastern Europe," in: Destination Branding: Creating the Unique Destination Proposition, $2^{\text {nd }}$ edition (eds. N. Morgan and A. Pritchard), Amsterdam et al 2004, [111]-127.

\section{KLEKOT 2010}

Ewa Klekot, "La visite du patrimoine national: entre politique et tourisme," Ethnologie française, 40/ (Pologne-Polska. Après le communisme), Paris 2010, 273-284.

\section{LEBE 1987}

Reinhard Lebe, Als Markus nach Venedig kam. Venezianische Geschichte im Zeichen des Markuslöwen), dtv Geschichte, Stuttgart 1987. 
176 |

MURDOCH 2007

Caitlin E. Murdoch, "Tourist Landscapes and Regional Identities in Saxony, 1878-1938," Central European History, 40, Cambridge 2007, 589621.

PAASI 2009

Ansi Paasi, "The Resurgence of the 'Region' and 'Regional Identity': Theoretical Perspectives and Empirical Observations on Regional Dynamics in Europe," Review of International Studies, 34, Cambridge 2009, 121-146.

\section{PALMER 1999}

Catherine Palmer, "Tourism and the symbols of identity," Tourism Management, 20, Amsterdam 1999, 313-321.

PALMER 2005

Catherine Palmer, "The Ethnography of Englishness. Experiencing Identity through Tourism," Annals of Tourism Research, 32/1, Amsterdam 2005, 7-27.

POSCH 2012

Eva Posch, "Kontextualisierung als ein Problembereich der touristischen Historiographie. Eine Analyse aktueller touristischer Medien aus Sibiu/Hermannstadt," Danubiana Carpathica, 6/53, Munich 2012, 291314.

POSCH 2015

Eva Posch, "Negotiating the Nation in Tourist Historiography from the Republic Moldova," revue d'études comparatives est-ouest, 46/1, Paris 2015, 161-184.

RIVERA 2008

Lauren A. Rivera, "Managing 'Spoiled' National Identity - War, Tourism, and Memory in Croatia," American Sociological Review, 73/4, Los Angeles et al 2008, 613-634.

ROJEK 1997

Chris Rojek, "Indexing, Dragging and the Social Construction of Tourist Sights," in: Touring Cultures. Transformations of Travel and Theory (eds. C. Rojek, J. Urry), New York 1997, 52-74. 
ROTHMAN 2012

E. Natalie Rothman, Brokering Empire. Transimperial Subjects between Venice and Istanbul, Ithaca et al 2012.

SEARS 1989

John F. Sears, Sacred Places. American Tourist Attractions in the Nineteenth Century, New York et al 2012.

SHAFFER 2001

Marguerite S. Shaffer, See America First. Tourism and National Identity, 1880-1940, Washington et al 2001.

TCHOUKARINE 2010

Igor Tchoukarine, "The Yugoslav Road to International Tourism: Opening, Decentralization, and Propaganda in the early 1950s," in: Yugoslavia's Sunny Side: A History of Tourism in Socialism (1950s-1980s) (eds. H. Grandits and K. Taylor), Budapest et al 2010, 109-140.

WÖHLER ET AL. 2010 Karlheinz Wöhler et al, "Formen und Konstruktionsweisen von Tourismusräumen," in: Tourismusräume. Zur soziokulturellen Konstruktion eines globalen Phänomens (eds. K. Wöhler, A. Pott and V. Denzer), Bielefeld 2010, 11-20.

\section{ZUELOW 2009}

Eric G. E. Zuelow, Making Ireland Irish. Tourism and National Identity since the Irish Civil War, Syracuse 2009. 